\title{
Penentuan Alternatif Material Part ABS Untuk Menjamin Kesinambungan Pasokan Pada Perusahaan Manufaktur Sepeda Motor
}

\author{
M. Yani Syafei ${ }^{1}$, Tri Sutrisno ${ }^{1}$ \\ 1) Faculty of Engineering, Industrial Engineering Department, President University \\ Jl. Ki Hajar Dewantara \\ Kota Jababeka,Cikarang, Bekasi - Indonesia 17550 \\ Email: yanisyafei@president.ac.id , tri.st250491@gmail.com
}

\begin{abstract}
ABSTRAK
Menjamin kesinambungan pasokan material dalam sistem manufaktur merupakan faktor yang sangat penting guna menjamin kelancaran proses produksi dan pemenuhan produk ke konsumen. Sebuah perusahaan manufaktur sepeda motor yang memiliki beberapa supplier injeksi part plastik, namun yang menjadi kendala adalah dari beberapa supplier injeksi part plastik hanya mengambil dari satu supplier material dengan merek dagang ABS-J. Single supplier ini sangatlah beresiko dari segi kemampuan penyediaan material dan juga adanya kemungkinan monopoli harga yang dapat dilakukan oleh supplier material karena tidak memiliki pesaing. Dengan metode pendekatan PDCA dilakukan penelitian untuk melakukan penentuan penambahan alternatif material ABS untuk menjamin ketersediaan pasokan material dan juga mendapatkan potensial profit yang dapat diperoleh dengan menerapkan multi supplier material ABS. Dengan metode trial and error penggunaan alternative material lain yaitu ABS Star dan juga anlisa fishbone dapat diperoleh hasil kualitas yang sama dengan material regular ABS-J, yaitu dengan melakukan perubahan setting parameter mesin injeksi. Setting parameter bereorientasi kepada penurunan suhu material yaitu menurunkan suhu barrel menjadi (230-225$220-200^{\circ} \mathrm{C}$ ), menurunkan speed injeksi (45-55-45-35) dan menggunakan holding press (70 Pa) untuk material ABS Star.
\end{abstract}

Kata Kunci: Alternatif Material, Pasokan, Material ABS, Single Supplier, Penambahan Supplier Material.

\section{ABSTRACT}

Ensuring the continuous supply of materials in the manufacturing system is a very important factor in ensuring the smooth production process and product fulfillment to consumers. A motorcycle manufacturing company that has several plastic parts injection suppliers, but the problem is that some plastic parts suppliers only take from one material supplier with the trademark ABS-J. This single supplier is very risky in terms of the ability to supply materials and also the possibility of a price monopoly that can be done by material suppliers because they have no competitors. With the PDCA approach, research is conducted to determine the addition of alternative ABS materials to ensure material supply availability and also obtain potential benefits that can be obtained by implementing multi-ABS material suppliers. With the trial-and-error method of using other alternative materials, namely ABS Star and also fish bone analysis, can get the same quality results as ordinary ABS-J material, by changing the injection machine parameter settings. The parameter setting is oriented towards reducing the temperature of the material by lowering the temperature of the barrel to (230-225-220-200 $\left.{ }^{\circ} \mathrm{C}\right)$, reducing the injection speed (45-55-45-35) and using Holding Pressure (70 Pa) for ABS Star material.

Keywords: Alternative Materials, Supply, ABS Material, Single Supplier, Addition of Supplier Material.

\section{Pendahuluan}

Dalam dunia industri manufaktur khususnya otomotif, keberlangsungan dan kesinambungan distribusi material atau part merupakan faktor yang sangat penting agar proses produksi tidak mengalami kendala yang disebabkan oleh supplier yang tidak dapat mengirim material ke perusahaan. Penjaminan ketersediaan material merupakan hal mutlak yang harus dikontrol penuh oleh bagian terkait untuk mencegah hal-hal yang tak terduga terutama off-produksi. Perusahaan yang mampu bertahan dipasaran adalah perusahaan yang mampu memenuhi keinginan konsumen dengan melakukan pembaruan terhadap produk, dapat mengirim 
tepat waktu dan memberikan harga yang rendah dalam produksi dan juga delivery (Wirdianto \& Unbersa, 2008). Salah satu hal yang harus dilakukan perusahaan pada persaingan bisnis adalah memberikan harga yang murah kepada konsumen tanpa mengurangi kualitas dari produk. Maka dari itu untuk memperoleh hal tersebut perusahaan harus dapat menekan biaya-biaya yang muncul, salah satunya adalah biaya dari supplier atau pemasok.

Perusahaan manufaktur otomotif terkenal di Indonesia merupakan suatu perusahaan manufaktur otomotif yang memproduksi sepeda motor dengan kapasitas produksi yang besar lebih dari 1 juta unit per tahun. Jumlah produksi yang tinggi ini harus tercapai guna memenuhi keinginan konsumen secara tepat waktu dan juga dengan harga yang rendah sehingga pemenuhan material untu produksi harus selalu tersedia. Dalam hal ini ini pemilihan dan penentuan supplier material sangatlah penting untuk dilakukan control dan bila perlu harus dilakukan penambahan supplier guna menjamin ketersediaan material (Mangla, et al., 2019).

Pemilihan dan penentuan supplier akan sangat beresiko jika supplier yang dipilih hanya satu supplier saja atau single supplier. Dikarenakan segala potensi kemungkinan terburuk tetap saja dapat terjadi dari potensi untuk (1) Pembuatan material atau part dan distribusi part terlambat karena material yang dibutuhkan tidak tersedia yang dapat dikarenakan faktor internal supplier material atau juga dapat dari faktor eksternal, (2) dan bahkan dengan penerapan hanya single supplier, supplier material dapat dengan sengaja melakukan monopoli harga yang dapat merugikan perusahaan.

Pada produksi part-part plastik sepeda motor, pihak perusahaan telah memiliki beberapa supplier injeksi yang kompeten untuk mensupply part ke perusahaan. Namun ada hal yang terlupakan dan menjadi sangat krusial dimana dari beberapa supplier injeksi yang menjadi supplier part perusahaan tersebut hanya satu perusahaan dengan satu merek produk yaitu ABS-J. Penggunaan material ABS-J ini untuk memenuhi kebutuhan dari seluruh produk sepeda motor untuk part-part plastik yang membutuhkan finish produk painting. Hal ini tentu sangatlah berbahaya untuk keberlangsungan produksi jika supplier material ABS-J ini mengalami kendala dalam produksi ataupun distribusi.

Dengan demikian, sebagai tujuan penelitian yaitu untuk mennetukan alternatif material dengan melakukan penambahan supplier material untuk mensupply material jenis ABS dari supplier lain, guna menjamin ketersediaan material dan juga menghindari adanya monopoli harga oleh supplier dan juga dapat memperoleh potensial profit dari selisih harga antara material.

\section{Metodologi Penelitian}

\subsection{Alur Penelitian}

Metodologi yang digunakan pada penelitian adalah dengan menggunakan pendekatan metode PDCA. PDCA merupakan langkah-langkah yang tersusun secara sistematis, mulai dari perencanaan atau Plan dengan mengumpulkan data dan mencari dasar penelitian, merencanakan perbaikan, kemudian masuk ke tahap Do yaitu melaksanakan perbaikan, Check dengan melakukan evaluasi hasil penelitian, kemudian terakhir adalah tahapan Action yaitu dengan melakukan standardisasi dan menetapkan rencana berikutnya (Sobek \& Smalley, 2008), (Gupta, 2006).

\subsubsection{Mengumpulkan Data dan Dasar Penelitian}

Dalam proses penentuan dasar penelitian, didasarkan pada teori risk management dimana perusahaan harus meminimalisir kemungkinan risiko yang timbul dalam suatu proses produksi. Dimana dalam hal ini penerapan single supplier dianggap terlalu berisiko untuk penjaminan ketersediaan material atau bahan baku produksi dan juga adanya monopoli dari harga material. Selain itu isu perang dagang China-AS menyebabkan material terutama yang diimpor mengalami kenaikan yang sangat signifikan, bahkan di kuartal 4 (Oktober-Desember) 2019 terjadi lonjakan harga yang signifikan pada material ABS-J sehingga hal ini dapat menyebabkan pembengkakan biaya produksi dikarenakan harga bahan material yang naik. Kenaikan harga material ABS-J yang signifikan menyebabkan adanya selisih harga dengan alternatif material lainnya sehingga ditargetkan dapat diperoleh profit dari adanya selisih harga ini. Serta berdasar pada target department, department mencanangkan untuk melakukan CR (Cost Reduction) sebesar 3\% dari target CR divisi sebesar 400M/Tahun, atau dengan kata lain target $C R$ yang ingin dicapai adalah sebesar $12 \mathrm{M} /$ Tahun. 


\subsubsection{Merencanakan Perbaikan}

Setelah didapat beberapa data yang dibutuhkan dalam penelitian, serta menentukan apa yang menjadi bahan utama untuk melakukan perbaikan, maka selanjutnya bersama tim penulis mencoba membuat rencana perbaikan apa yang harus dilakukan untuk mendapatkan target dari penelitian ini.

\subsubsection{Melaksanakan Perbaikan}

Setelah ditentukan rencana perbaikan apa yang akan diambil, kemudian penulis dan tim menerapkan rencana tersebut dalam aktual perbaikan, dimulai dari penentuan maker material kemudian membuat schedule trial di supplier injeksi kemudian baru dilakukan trial apakah material mampu digunakan dengan kemampuan mesin injeksi di supplier atau butuh suatu perlakuan khusus untuk material baru ini. Jika didapat part yang OK baru kemudian akan dilakukan evaluasi dari kualitas part.

\subsubsection{Evaluasi Hasil Penelitian}

Tahapan evaluasi adalah tahapan dimana setelah perbaikan kita lakukan, kemudian kita memantau hasil perbaikan itu selama periode tertentu yang ditetapkan oleh tim untuk melihat kestabilan kualitas dari part yang telah dihasilkan.

\subsubsection{Standardisasi}

Setelah semua aktivitas dinyatakan valid dan kualitas produk layak digunakan untuk produksi sepeda motor, selanjutnya supplier injeksi membuat kontrak kerja baru dengan menambahkan alternatif material kedua menjadi material yang diperbolehkan untuk digunakan memproduksi part-part order PT. Motor. Kemudian dilakukan approval part dengan melalui tahapan-tahapan yang telah ditetapkan oleh standard flow approval PT. Motor, sehingga part dapat diproduksi secara massal.

\subsubsection{Menetapkan Rencana Berikutnya}

Merupakan suatu tahapan dari flow PDCA yang digunakan untuk membuat rencana perbaikan yang berkesinambungan khususnya terkait dengan penelitian yang diambil untuk dapat diimplementasikan ke dalam scope yang lebih luas.

\section{Hasil dan Pembahasan}

\subsection{Pengumpulan Data dan Menentukan Dasar Penelitian}

ABS-J merupakan single material regular yang sekarang digunakan oleh supplier injeksi untuk membuat partpart plastik. Namun dikarenakan adanya kenaikan harga dan juga risiko keterlambatan sehingga penelitian ini dilakukan yaitu dengan mencari alternatif material lain.

Pada kuartal 4 tahun 2019, dampak dari perang dagang Amerika dan China menyebabkan pengiriman material ABS-J yang merupakan material utama untuk membuat part-part plastic sepeda motor menjadi terkendala karena pembatasan ekspor yang dilakukan oleh pasar global. Hal ini juga mengakibatkan harga material ABS-J mengalami kenaikan yang sangat signifikan seperti terlihat pada Gambar 1.

Pembatasan ekspor yang dilakukan oleh pasar global berdampak pada kenaikan harga sehingga menimbulkan risiko yang berbahaya bagi perusahaan, kenaikan harga ini akan berdampak pada kenaikan harga unit sepeda motor. Tentu hal ini tidak boleh terjadi di tengah-tengah persaingan yang semakin ketat dengan kompetitor. 


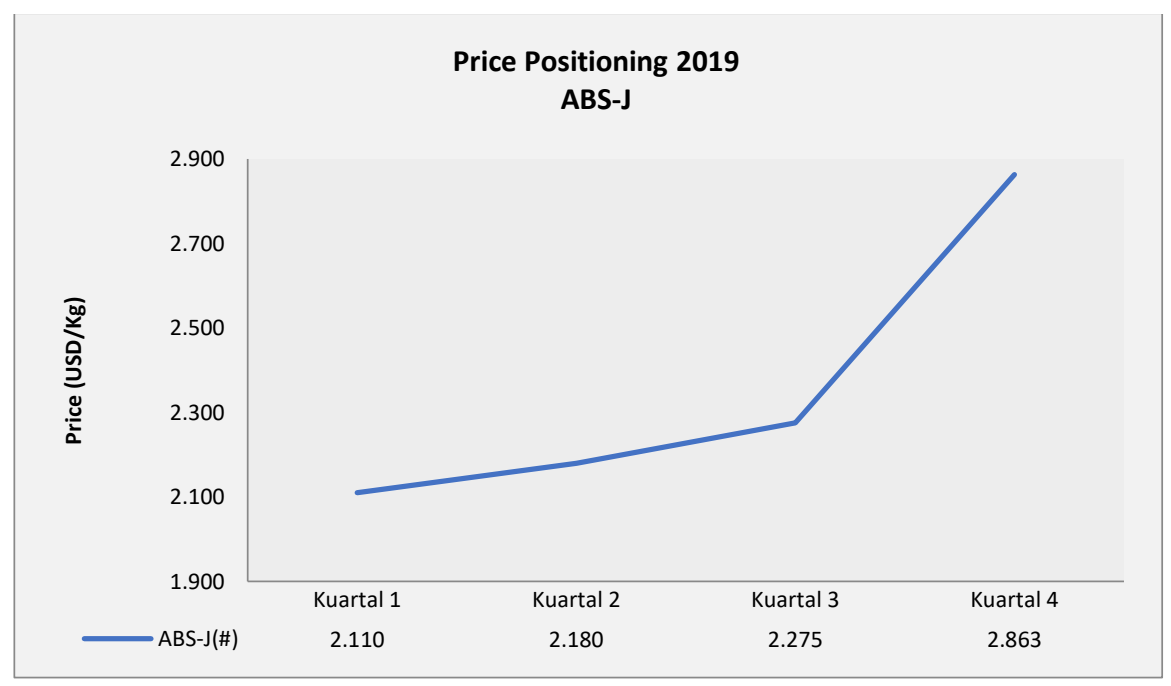

Sumber: (www.icis.com)

Gambar 1. Grafik Harga Material ABS-J Tahun 2019

Maka dari itu, penting sekali untuk melakukan analisis manajemen risiko rantai pasok atau supply chain risk management. Supply Chain Risk Management merupakan paduan antar dua konsep yaitu Supply Chain Management dan Risk Management itu sendiri (Brindly, 2004) atau dapat digambarkan pada Gambar 2 berikut ini.

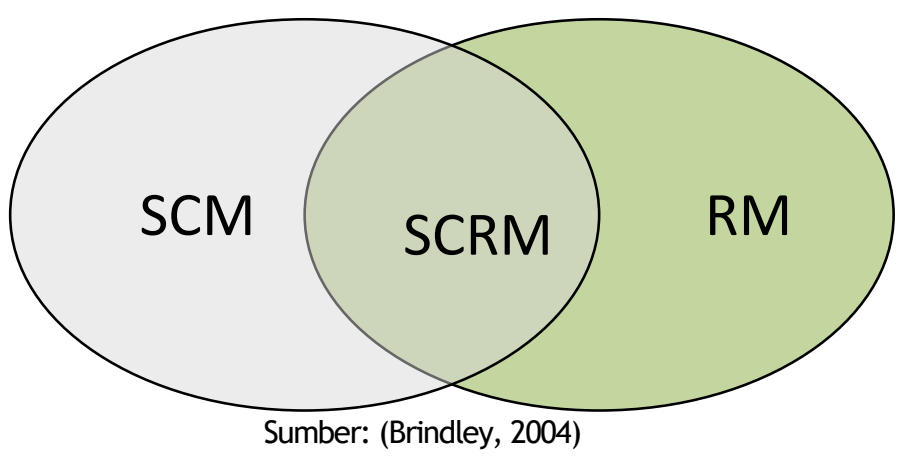

Gambar 2. Grafik Harga Material ABS-J Tahun 2019

Adapun Supply Chain Risk Management merupakan resiko yang dapat terjadi pada suatu aliran produk, bahan baku, informasi sampai dengan pengiriman produk akhir. Risiko ini dapat diartikan sebagai suatu kejadian yang disebabkan oleh ketidakseimbangan antara permintaan dan kemampuan pasok (Cristopher \& Peck,2003). Gangguan rantai pasok atau supply chain disruptions adalah kejadian yang tidak terencana atau terprediksi yang terjadi dalam rantai pasok yang dapat memengaruhi aliran bahan dan komponen. Gangguan ini dapat mengakibatkan beberapa permasalahan seperti waktu lead time yang semakin tinggi, stock out, keterlambatan pemenuhan kepada konsumen dan juga kenaikan biaya baik biaya pasok, produksi maupun pengiriman.

Sedangkan risiko dalam sistem rantai pasok dapat dibagi ke dalam tiga bagian kategori, yaitu: (Cristopher \& Peck,2003)

1. Risiko internal merupakan suatu risiko dimana perusahaan supplier mempunyai kontrol pada proses dan juga kontrol risiko.

a. Risiko proses adalah risiko yang timbul dari kegiatan operasional dan manajerial akibat terganggunya suatu proses.

b. Risiko kontrol adalah risiko yang muncul akibat suatu kesalahan dalam penerapan aturan yang ditetapkan oleh perusahaan. Misalnya: kebijakan stock, transportasi, order, dan lain-lain.

2. Risiko eksternal perusahaan namun masih dalam lingkup jaringan supply chain, meliputi risiko order dan risiko supply.

a. Resiko order atau permintaan merupakan resiko yang muncul akibat terganggunya suatu aliran produk dan informasi yang berhubungan dengan proses, kontrol, asset dan instruktur pada downstream. 
b. Resiko supply adalah resiko yang muncul akibat terganggunya aliran produk dan informasi yang berhubungan dengan proses, kontrol, dan instruktur pada upstream.

3. Risiko eksternal lingkungan

Risiko lingkungan ini adalah risiko yang disebabkan oleh faktor bencana alam, faktor politik, dan lainlain.

Kenaikan harga dan penerapan single supplier material dalam system supply chain di perusahaan motor tersebut berpotensi menimbulkan kerugian baik terhadap supplier injeksi maupun ke internal perusahaan, maka harus dicari alternatif penambahan supplier material untuk mendapatkan solusi dari permasalahan harga material yang naik dan juga adanya potensi keterlambatan supply material yang disebabkan oleh penerapan single supplier.

Penggunaan material di perusahaan, sudah ditentukan pada tiap-tiap drawing part oleh tim RnD dalam bentuk kode tertentu seperti terlihat pada Gambar 3 di bawah ini.

NOTE

1) STANDARD THICKNESH : $4,0 \pm 0.5$

2) MATERAL : ABS-I

3) MATERIAL COLOR: BLACK OR GRAY

Gambar 3. Kode Material Pada Drawing Part

Penggunaan material menggunakan kode material yang dapat diturunkan lagi berupa alternatif-alternatif berdasarkan standar dari department material perusahaan yang tertuang dalam Technical Confirmation Material. Dimana dari standar Technical Confirmation Material terdapat empat alternatif material ABS, yaitu:

1. ABS-J

2. ABS-I

3. $\quad A B S L N$

4. ABS Star

Alternatif-alternatif material ABS di atas memiliki karakteristik yang berbeda-beda yang dapat ditunjukkan pada Tabel 1 di bawah ini.

Tabel 1. Karakteristik Material ABS

\begin{tabular}{|l|c|c|c|c|}
\hline \multirow{2}{*}{\multicolumn{2}{c}{ Item Karakteristik }} & \multicolumn{5}{c|}{ Material } \\
\cline { 2 - 5 } & ABS-J(\#) & ABS-I(\#) & LN(\#) & Star $(\#)$ \\
\hline Izod Impact (Kg.cm/cm) & 32,5 & 23 & 22 & 36,9 \\
\hline Melt Flow Index (g/10 min) & 26 & 28,5 & 19,5 & 27 \\
\hline Deflection Temp. Load $\left({ }^{\circ} \mathrm{C}\right)$ & 93 & 79,7 & 82 & 98,1 \\
\hline
\end{tabular}

Izod impact adalah nilai dari ketahanan material dalam menahan suatu beban yang diberikan. Semakin besar nilai impact maka daya material tahan menerima beban dari luar semakin besar juga. Sedangkan Melt flow index merupakan nilai kekentalan suatu material. Nilai melt flow ini tergantung dari susunan rantai polimer, semakin rendah nilai melt flow maka material semakin kental.

Selain itu juga perlu diperhatikan harga dari tiap-tiap alternatif material yang ditunjukkan pada Gambar 4. Pada latar belakang penelitian disebutkan bahwa pada kuartal empat 2019 terjadi kenaikan harga yang signifikan pada material regular yaitu material ABS-J. Berdasarkan gambar tersebut, harga material dari kuartal 1 sampai dengan kuartal 3 relatif stabil dengan posisi ABS-J menempati posisi paling atas atau mahal dari jenis material lainnya. Namun pada kuartal 4 terjadi lonjakan harga yang dikarenakan isu persaingan dagang antara Amerika dan China yang sedang terjadi, sehingga pembelian bahan baku material dibatasi yang berdampak pada kenaikan harga. 


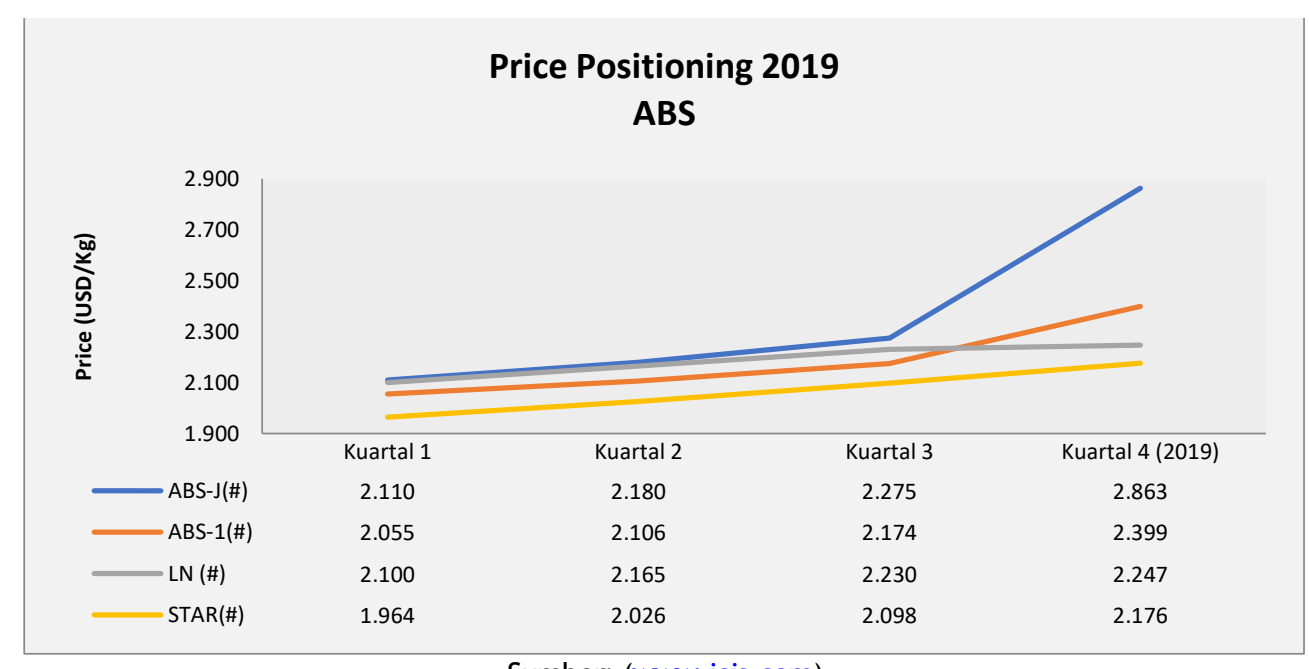

Sumber: (www.icis.com)

Gambar 4. Harga Material ABS

Kemudian posisi selanjutnya ada ABS-I yang trend harganya sama dengan ABS-J dimana pada kuartal 4 terjadi lonjakan harga hal ini karena supplier bahan baku sama yaitu dari mancanegara. Turun ke harga lebih rendah berikutnya adalah jenis LN cenderung ada penurunan harga dan terakhir adalah jenis ABS Star material cenderung naik tapi posisi dari harga material adalah yang paling bawah atau murah dibanding dengan material lainnya hal ini dikarenakan supplier material untuk jenis ini berasal dari dalam negeri, sehingga persaingan dagang Amerika dan China tidak berdampak terlalu besar.

Dengan menggunakan diagram pareto yang disajikan pada Gambar 5 , dilakukan analisis penggunaan material ABS-J di tiap-tiap supplier injeksi, hal ni dilakukan untuk efektivitas penelitian untuk mendapatkan hasil yang maksimal dengan waktu dan biaya yang cenderung relatif kecil.

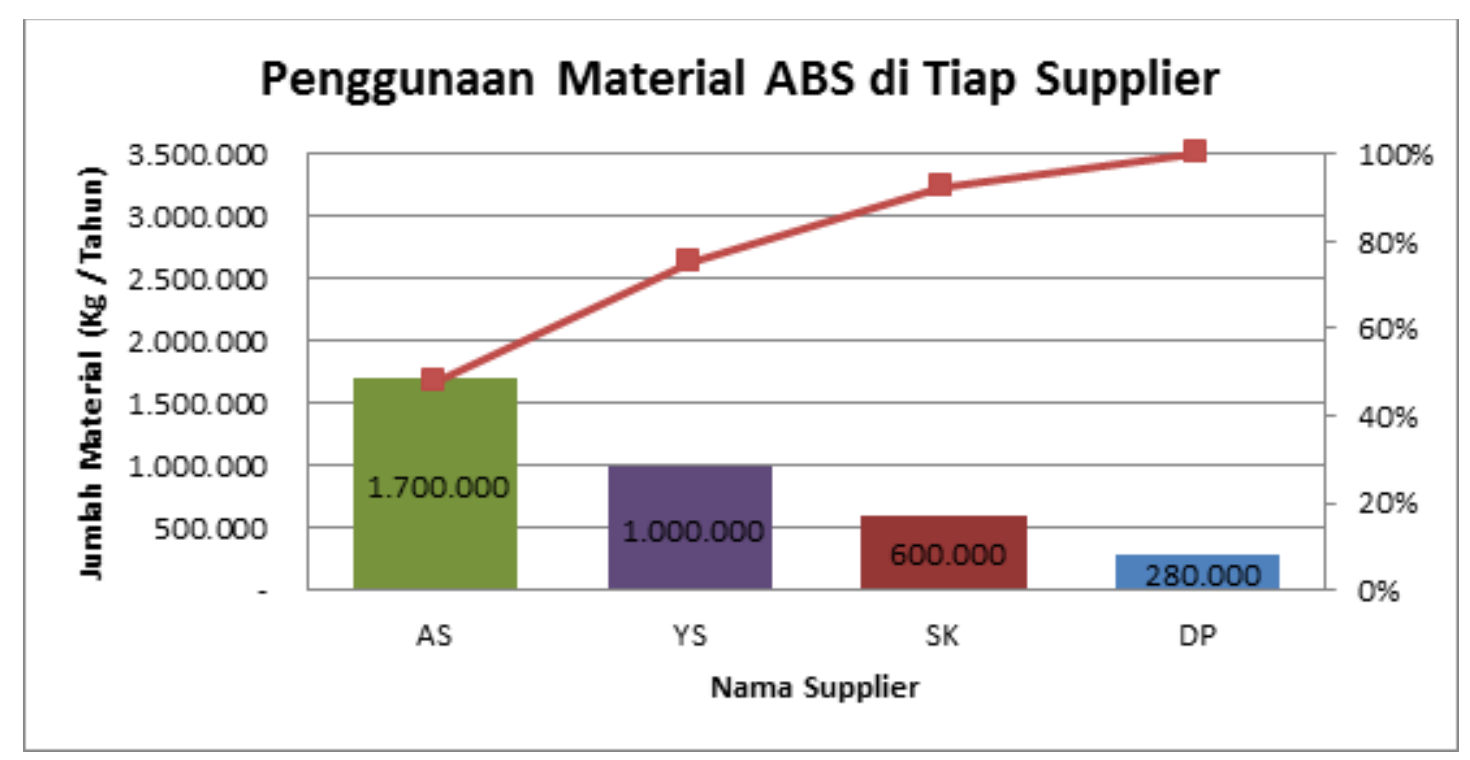

Gambar 5. Diagram Pareto Penggunaan Material ABS-J di Supplier Injeksi

Dari standar material dan data yang ditunjukkan, maka penelitian yang akan dilakukan yaitu dengan mencari alternatif material baru untuk produksi part-part plastik di perusahaan tersebut dengan menggunakan material ABS Star.

\subsection{Merencanakan Perbaikan Penggunaan Material ABS Star}

Dalam merencanakan perbaikan maka ada hal yang harus diperhitungkan terlebih dahulu yaitu benefit yang akan diperoleh jika menggunakan alternatif material baru. Perbedaan harga material antara ABS-J dan ABS Star dapat dilihat pada Tabel 2 di bawah ini. 
Tabel 2. Perbedaan Harga Material ABS-J dan ABS Star

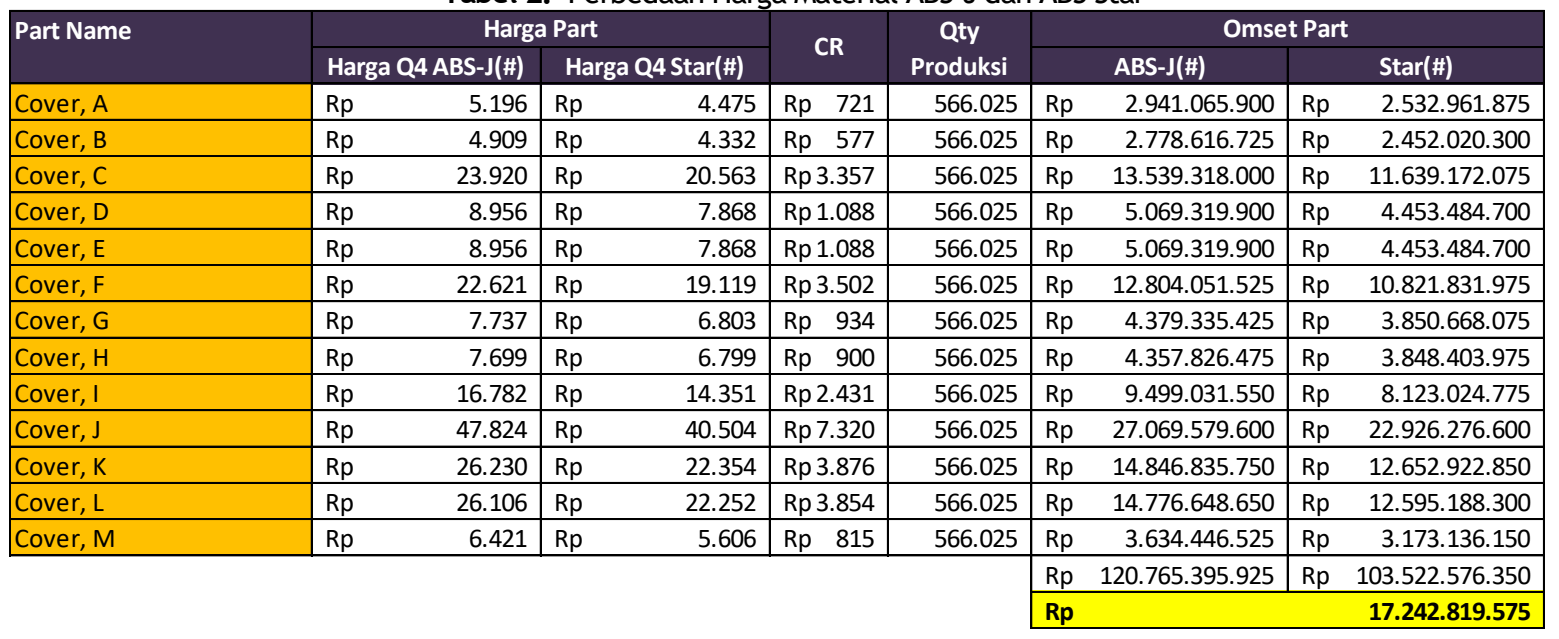

Dengan jumlah nilai forecast produksi di tahun 2020 untuk tipe sepeda motor M S yang sebesar 566.025 unit (data internal), maka dapat diperoleh selisih harga dan juga potensial profit yang dapat diperoleh sebesar Rp 17.242.819.575,- (Tujuh belas miliar dua ratus empat puluh dua juta delapan ratus sembilan belas ribu lima ratus tujuh puluh lima rupiah).

\subsection{Melakukan Perbaikan Penggunaan Material ABS Star}

\subsubsection{Trial Penggunaan Material ABS}

Trial yang dilakukan adalah dengan langsung mengganti material tanpa melakukan perubahan apapun, hasilnya seperti disajikan pada Tabel 3 di bawah ini.

Berdasarkan data pada table tersebut menunjukkan hasil cacat yang terjadi saat dilakukan trial. Di awal injeksi part mengalami shortshoot, yaitu kondisi part tidak terisi penuh oleh material sebanyak 2 pcs, hal ini umum terjadi di awal proses dikarenakan suhu mold belum panas. Namun pada injek part berikutnya part selalu flash dan sinkmark. Hal ini butuh dilakukan analisis yang lebih lanjut kenapa bisa terjadi reject flash dan sinkmark.

Tabel 3. Kualitas Part Trial

\begin{tabular}{|c|c|c|c|}
\hline \multirow{2}{*}{ Part No. } & \multicolumn{3}{|c|}{ Jenis Cacat } \\
\hline & Flash & Sinkmark & Shortshoot \\
\hline 1 & & & $\mathrm{~V}$ \\
\hline 2 & & & $\mathrm{~V}$ \\
\hline 3 & $\mathrm{~V}$ & $\mathrm{~V}$ & \\
\hline 4 & $\mathrm{~V}$ & $\mathrm{~V}$ & \\
\hline 5 & $\mathrm{~V}$ & $\mathrm{~V}$ & \\
\hline 6 & $\mathrm{~V}$ & $\mathrm{~V}$ & \\
\hline 7 & $\mathrm{~V}$ & $\mathrm{~V}$ & \\
\hline 8 & $\mathrm{~V}$ & $\mathrm{~V}$ & \\
\hline 9 & $\sqrt{ }$ & $\mathrm{V}$ & \\
\hline 10 & $\mathrm{~V}$ & $\mathrm{~V}$ & \\
\hline 11 & $\mathrm{~V}$ & $\mathrm{~V}$ & \\
\hline 12 & $\mathrm{~V}$ & $\mathrm{~V}$ & \\
\hline 13 & $\sqrt{v}$ & $\mathrm{~V}$ & \\
\hline 14 & $\mathrm{~V}$ & $\mathrm{~V}$ & \\
\hline 15 & $\mathrm{~V}$ & $\mathrm{~V}$ & \\
\hline 16 & $\mathrm{~V}$ & $\mathrm{~V}$ & \\
\hline 17 & $\sqrt{ }$ & $\mathrm{V}$ & \\
\hline 18 & $\mathrm{~V}$ & $\mathrm{~V}$ & \\
\hline 19 & $\mathrm{~V}$ & $\mathrm{~V}$ & \\
\hline 20 & $\mathrm{~V}$ & $\mathrm{~V}$ & \\
\hline
\end{tabular}




\subsubsection{Analisis Penyebab}

Pada analisis penyebab ini digunakan fishbone diagram. Fishbone diagram merupakan suatu diagram yang digunakan untuk mencari tahu apa penyebab dari suatu kejadian yang berbentuk menyerupai tulang ikan dengan memiliki pengelompokan kategori Material, Machine, Man, Method dan Environment (Mitra, 2016). Adapun hasil analisis penyebab terjadinya reject pada part tersebut, disajikan pada diagram fishbone yang disajikan pada Gambar 6.

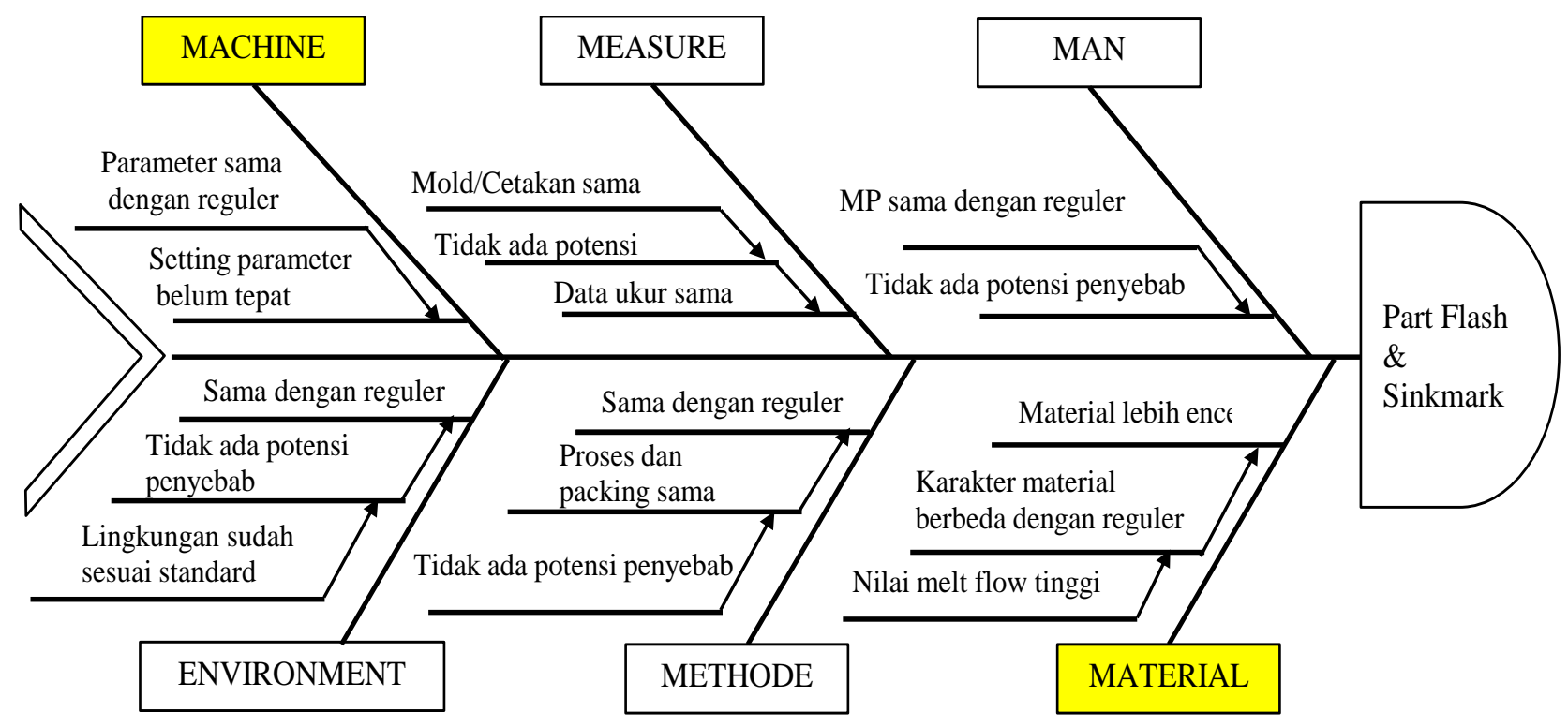

Gambar 6. Fishbone Diagram Penyebab Part Flash \& Sinkmark

Berdasarkan diagram Fishbone, maka penyebab part flash \& Sinkmark tersebut diperoleh beberapa faktor yang dapat menjadi penyebab, yaitu:

1. Nilai melt flow material ABS Star lebih tinggi, sehingga material lebih encer daripada ABS-J.

2. Parameter setting mesin injeksi sama dengan part regular (ABS-J), namun ternyata belum tepat untuk material ABS Star.

\subsubsection{Trial Perbaikan Perubahan Setting Parameter Mesin}

Pada trial ini yang dilakukan adalah fokus pada penurunan suhu material seperti dijelaskan pada analisis fishbone diagram di atas, yaitu dengan melakukan perubahan setting parameter untuk menyamakan karakteristik material (Hart, 2003), yaitu dengan cara:

1. Menurunkan suhu mesin di barel

2. Menurunkan speed injeksi

3. Menaikkan holding press mesin

Berdasarkan hasil perbaikan perubahan setting parameter mesin, maka hasil trialnya disajikan pada Tabel 4. Dari hasil trial diperoleh setting parameter mesin yang paling tepat adalah pada trial kelima yaitu dengan setting parameter pada:

1. Suhu barrel $\left({ }^{\circ} \mathrm{C}\right): 230-225-220-200$

2. Speed Injeksi $(\mathrm{m} / \mathrm{s}): 45-55-45-35$

3. Holding Pess $(\mathrm{Pa}): 70$ 
Tabel 4. Hasil trial dan Error Setting Parameter Penggunaan Material ABS Star

\begin{tabular}{|c|c|c|c|c|}
\hline $\begin{array}{l}\text { No. } \\
\text { Trial }\end{array}$ & Item & ABS-J(\#) & ABS Star(\#) & Result \\
\hline \multirow{3}{*}{1} & Suhu Barrel $\left({ }^{\circ} \mathrm{C}\right)$ & $240-240-230-220$ & $200-200-200-200$ & \multirow{3}{*}{ Short Shoot } \\
\hline & Speed Injeksi $(\mathrm{m} / \mathrm{s})$ & $55-55-60-45$ & $35-35-35-35$ & \\
\hline & Holding Press $(\mathrm{Pa})$ & 65 & 70 & \\
\hline \multirow{3}{*}{2} & Suhu Barrel $\left({ }^{\circ} \mathrm{C}\right)$ & $240-240-230-220$ & $235-225-230-225$ & \multirow{3}{*}{ Part Gosong } \\
\hline & Speed Injeksi (m/s) & $55-55-60-45$ & $45-45-45-35$ & \\
\hline & Holding Press $(\mathrm{Pa})$ & 65 & 68 & \\
\hline \multirow{3}{*}{3} & Suhu Barrel $\left({ }^{\circ} \mathrm{C}\right)$ & $240-240-230-220$ & $220-225-220-200$ & \multirow{3}{*}{ Silver } \\
\hline & Speed Injeksi $(\mathrm{m} / \mathrm{s})$ & $55-55-60-45$ & $45-45-45-45$ & \\
\hline & Holding Press $(\mathrm{Pa})$ & 65 & 70 & \\
\hline \multirow{3}{*}{4} & Suhu Barrel $\left({ }^{\circ} \mathrm{C}\right)$ & $240-240-230-220$ & $230-225-220-200$ & \multirow{3}{*}{$\begin{array}{l}\text { Sink Mark \& } \\
\text { Deformasi }\end{array}$} \\
\hline & Speed Injeksi (m/s) & $55-55-60-45$ & $45-50-45-35$ & \\
\hline & Holding Press $(\mathrm{Pa})$ & 65 & 65 & \\
\hline \multirow{3}{*}{5} & Suhu Barrel $\left({ }^{\circ} \mathrm{C}\right)$ & $240-240-230-220$ & $230-225-220-200$ & \multirow{3}{*}{ OK } \\
\hline & Speed Injeksi (m/s) & $55-55-60-45$ & $45-55-45-35$ & \\
\hline & Holding Press $(\mathrm{Pa})$ & 65 & 70 & \\
\hline
\end{tabular}

\subsection{Evaluasi Hasil Penelitian}

Setelah didapat setting parameter yang tepat, kemudian dilakukan evaluasi kualitas part dengan cara melakukan injeksi secara terus menerus sampai 200 pcs. Hal ini untuk mengetahui ability part dengan menggunakan material ABS Star. Di perusahaan untuk batas part reject yang diizinkan hari injek 200 pcs adalah maksimal 10 pcs atau dengan kata lain sebesar $5 \%$. Pada hasil evaluasi penelitian ini diperoleh ability part dengan part reject sebanyak 4-part atau hanya $2 \%$. Artinya part dengan menggunakan material baru dinyatakan dapat digunakan untuk produksi part plastik sepeda motor.

\subsection{Standardisasi}

Tahapan standardisasi pada penelitian ini dengan aktivitas, yaitu:

1. Membuat kontrak kerja baru antara PT. Motor dan supplier injeksi dengan penerapan multi supplier, seperti terlihat pada Tabel 5 berikut ini.

Tabel 5. Kontrak Kerja baru

\begin{tabular}{|l|c|c|c|}
\hline $\begin{array}{c}\text { MATERIAL } \\
\text { (BaSE On DWg) }\end{array}$ & INPLANT & OUTPLANT & NAMA S/C \\
\hline$\cdot$ & 0 & & PT. AS INDONESIA \\
\hline Mat Std: ABS-1 & & & \\
\hline Mat ACt: & & 0 & PT. SO \\
\hline ABS T & & 0 & PT. TO \\
\hline ABS STAR & & 0 & PT. DI \\
\hline MASTERBATCH BLACK & & & \\
\hline
\end{tabular}

2. Membuat approval part dengan melakukan registrasi part nomor untuk melakukan proses order part dari perusahaan manufaktur motor ke supplier injeksi. 


\section{Kesimpulan}

Penerapan alternatif material baru pada standar material ABS dapat dilakukan. Dalam penelitian ini penetapan alternatif material adalah material ABS Star. Hasil yang diperoleh dengan penggunaan material baru ini awalnya berbeda, namun dapat disamakan dengan cara mengubah setting parameter mesin injeksi, yaitu dengan melakukan:

1. Menurunkan Suhu barrel menjadi $\left({ }^{\circ} \mathrm{C}\right): 230-225-220-200$

2. Menurunkan Speed Injeksi (m/s) menjasi : 45-55-45-35

3. Meningkatkan Holding Pess menjadi (Pa) : 70.

Adapun untuk menghasilkan alternatif material lain yang lebih baik, dapat dilakukan percobaan lebih lanjut dimana tidak hanya mengandalkan dari alternatif material ABS Star, sehingga sedemikian rupa dapat diperoleh beberapa alternatif material plastik yang memiliki kualitas yang sama serta harga yang relatif sama.

\section{References}

1. Brindly, Claire. 2017. "Supply Chain Risk”. Routledge - Taylor \& Francis Group, New York, USA

2. Cristopher, M., \& Peck, H. 2003. "BuildingThe Resilient Supply Chain". International Journal of Logistics Management. 15(12).p.1-14., Cranfield School of Management,

3. Gupta, P. Beyond PDCA A New Process Managemant Model, 2006, https://www.researchgate.net/profile/Praveev_Gupta13/publication/259497347_Beyond_PDCA _A_new_process_management_model/links/553dc84a0cf29b5ee4bcdf50/Beyond-PDCAAnewprocess-mangement-model.pdf, diakses 28 November 2019.

4. Hart, Horald. 2003. Organic Chemistry. Penerjemah : Suminar Setiati Achmadi. Kimia Organik. Jakarta : Erlangga.

5. Mangla, Sachin K.; Luthra, Sunil; Jakhar, Suresh Kumar, et al, 2019. Sustainable Procurement in Supply Chain Operations. CRC Press, Taylor \& Francis Group, New York, USA.

6. Mitra, Amitava., 2016. Fundamentals of Quality Control and Improvement, John Wiley \& Sons, Inc.

7. Sobek, Durward K., \& Smalley, Art, 2008. Understanding A3 Thinking: A Critical Component of Toyota's PDCA Management System. CRC Press, Taylor \& Francis Group, New York, USA.

8. Wirdianto, E dan Unbersa, E. 2008. Aplikasi Metode Analytical Hierarchy Process Dalam Menentukan Kriteria Penilaian Pemasok. Jurnal Teknika, No. 29 Vol.2 Thn. XV April 2008 